\title{
AN INTERLANGUAGE PHONOLOGICAL APPROACH TO THE ANALYSIS OF SELECTED GHANAIAN NEWSCASTERS' RENDITIONS
}

\author{
Mariam Titilope Gobir ${ }^{1 *}$ and Victoria Dankyi Adwoa ${ }^{2}$ \\ ${ }^{1}$ Department of English and Linguistics, Kwara State University, Malete, Nigeria \\ Email: mariam.gobir@kwasu.edu.ng \\ ${ }^{2}$ Department of English and Linguistics, Kwara State University, Malete, Nigeria \\ torrieberks@gmail.com
}

Cite this article:

Mariam T.G., Victoria D.A. (2022), An Interlanguage Phonological Approach to the Analysis of Selected Ghanaian Newscasters' Renditions. International Journal of Literature, Language and Linguistics 5(1), 1-16. DOI: 10.52589/IJLLL-EUNTS7SZ

\section{Manuscript History}

Received: 6 Jan 2022

Accepted: 29 Jan 2022

Published: 14 Feb 2022

Copyright $@ 2022$ The Author(s). This is an Open Access article distributed under the terms of Creative Commons AttributionNonCommercial-NoDerivatives 4.0 International (CC BY-NC-ND 4.0), which permits anyone to share, use, reproduce and redistribute in any medium, provided the original author and source are credited.
ABSTRACT: In recent years, specially marked varieties of the English language have been the thrust of many researches, and the Ghanaian English is one of them. This study examined selected Ghanaian newscasters' renditions using the tenets of Selinker's Interlanguage Phonology Theory: simplification, overgeneralisation of the L2 and transfer. The study also incorporated the use of Praat application for the analysis of the data. Apart from this, the interview method was used to collect the data for the study. The data collected consist of interviews recorded across twelve radio stations in Cape-Coast, Ghana. The data analysis revealed that some phonemes of the British English $(B r E)$ are unavailable in the Ghanaian English; hence, the newscasters introduce or transfer some of the phonemic features that are characteristics of the individual's variety into the British English (BrE), especially those with similar phonemic properties. Also, phonological simplification processes were introduced by the respondents to enable them to produce words easily and as a result, the words and syllables end up reduced, restructured or re-syllabified. In conclusion, the findings from the study have reflected that there are modifications by the studied speakers and these modifications are what make the English language spoken by the newscasters distinct from what is obtainable on the job, due to the exigencies of the second language situation and specific cognitive oriented problems.

KEYWORDS: Interlanguage, Individual Competence, Performance, Simplification, Circumlocution. 
International Journal of Literature, Language and Linguistics

ISSN: 2689-9450

Volume 5, Issue 1, 2022 (pp. 1-16)

www.abjournals.org

\section{INTRODUCTION}

It is a general knowledge that West Africa was colonized by the Britons and English Language is the designated official language of many African nations, among which is Ghana (Ammon, 1992, pp.78-81) English language is hegemonic in Ghana as it is in Nigeria and other British colonies, since it is used for communication, day to day activities, education, religion, business, etc.

However, it is widely known that the Ghanaian spoken English varies from the accent of other West African nations. Also, the Ghanaian English, in terms of the accent, to be precise, has sub-varieties based on location, context, and interference of the mother tongue. Despite this, newscasters are perceived to be eloquent, intelligent and have been trained on the job to speak better than a layman in the Ghanaian environment. Therefore, the researcher seeks to verify the claim on whether the newscasters speak better than the layman outside of their job.

The aim of this study is to embark on an analysis of the selected Ghanaian newscasters' rendition using the interlanguage phonological approach in order to verify the claim regarding the proficiency of the Ghanaian newscasters over others in the Ghanaian environment.

\section{LITERATURE AND THEORETICAL REVIEW}

This section contains an empirical review of the phonology of Ghanaian English as well as the discussion of the theoretical approach for the study - interlanguage phonology.

\section{Phonology of Ghanaian English}

Ghanaian English (GhE) has been described phonologically by scholars like Sey (1973), Dako (2001), Koranteng (2006), Quartey (2009), Ofori (2002), and a few others. These scholars claim that the GhE is short of some speech sounds of the Received Pronunciation (RP), including the features of variation. Ofori et al. (2014, p.53) reported that the nasal velar is totally deleted from the GhE. To Koranteng (2006, p.332), /n/ has a phonetic realization of $/ \mathrm{n} /$ in GhE. He further added that the nasal velar $/ \mathrm{n} /$ may be realised as $/ \mathrm{n} /$ as in [Өank] for [Өænk]; or [du:In/ for /du:In/. /n/ is just a pre-velar allophone of $/ \mathrm{n} /$ in Ghanaian English. This implies that the Ghanaian English does not have the /n/ sound in its sound inventory; hence, the replacement of $/ \mathrm{n} /$ sound with /n/. Huber (2008) maintained that the Ghanaian English, unlike the RP, allow /ng/ in coda sequence in words like sing or song. He added that the nasal velar $/ \mathrm{n} /$ may be realised as $/ \mathrm{n} /$ or $/ \mathrm{g} /$ in some pronunciations. However, Dako (2001) stated that the deviation from RP consonant occurs in few cases and usually among younger speakers who are familiar with the use of the sound. All these ask the question of the variation of the representation of the nasal among Ghanaians.

Also, Ghanaians substitute the /æ/ vowel for $/ \Lambda$ / with the Hausa accent of northern Nigeria. Not just this sound but some other sounds as well. Nevertheless, Ghana has tried to distinguish herself in West Africa with this pattern of restructuring $/ \Lambda /$, which is basically as a result of their sensitivity to stigmatized forms and their ever readiness to change to the fashionable form. Apart from this, there is the patterning and restructuring of the /3:/ in the Ghanaian English.

There is also the restructuring of the schwa / $/$ sound in Ghanaian English. The schwa sound $/ \gamma /$ is a very distinctive vowel and it is difficult to pronounce in many parts of West Africa. As 
a result of this, it is taught at all levels, but then, in all parts of West Africa, this sound is rendered differently from how it is in the BrE. Variants of this sound are produced or represented in all parts of West Africa, such as [or, er, ous, um, our]. This is likely due to how difficult it is to produce or because it is lacking in the sound inventories of nations in West Africa. However, this trend contrasts with the main Ghanaian pattern and it is quite astonishing how the Ghanaians produce this sound differently from the rest of the other British colonies. In Ghana, the schwa sound / $/$ is perceived as the /a:/ sound. This constitutes researches carried out by Adjaye, Sey, etc.

Another problem associated with the Ghanaian English is the deviant usage in the pronunciation of RP vowels. Examples of these vowels and their words are:

/æ/ - "cat", /a:/ - "palm", /ø/ - "letter"; all three vowels are realised or produced as /a/; / / "bus", /p/ - "hot", both vowels are produced as /J/; /u:/ - "food", /u/- "put", both vowel are pronounced as /u:/, /ə/; "first" pronounced /3:/; /i:/ - "meet", /i/ - "six", produced as /i:/ (Sey, 1973).

Another distinctive feature of GhE pronunciation is spelling pronunciation. Ngula maintained that spelling pronunciation is pervasive in the English spoken by educated Ghanaians and this is largely influenced by two inseparable factors which are the inconsistent relationship between English orthography and sound, and the converse situation in the L1 language, which the majority of Ghanaians first acquire. He then proposed that spelling pronunciation qualifies as one of the innovative features of pronunciation that are giving Ghanaian English a character that is different from standard native Englishes. Examples include /kauntri/ for / kıntri/ "country"; /digit/ for /didşit/ - "digit"; and /kastil/ for /ka:sl/ "castle" (Ngula, 2011, pp. 30-31).

In conclusion, in the Ghanaian English, there seems to be some sort of unique redundancies. There are some sort of redundancies in the speech of many educated Ghanaians. For instance, hypercorrections like, fi/n/er, stro/n/er, etc. It is quite evident that the speakers are trying to mark themselves out from the spelling pronunciation in fin $/ \mathrm{g} / \mathrm{er}$, stron/g/er.

\section{Interlanguage Phonology}

Interlanguage phonology theory functions as an approach to the theoretical model for this study. Larry Selinker coined the term "interlanguage phonology" and he was of the view that interlanguage is based on the theory that there is a dormant psychological framework in the human brain that is activated when there are attempts to learn a second language (Selinker, 1972).

He also opined that to study the psychological processes involved, one can compare the interlanguage utterances of the learner with the utterances in the native languages (L2) to convey the same message pronounced by the learner and then compare as well the utterances in the target language (L2) to convey the same messages produced by the native speaker of that language. He added that, it is possible to apply an interlanguage perspective to a learner's underlying knowledge of the target language sound system (interlanguage phonology), grammar (morphology and syntax), vocabulary (lexicon) and language-use nouns found among learners (interlanguage pragmatics).

The possible markers of interlanguage phenomenon are interference/transfer, simplification, circumlocution and overgeneralisation. 
- Interference/transfer refers to the influence of one language or variety on another in the speech of bilinguals who use both languages.

- Simplification deals the second language that has been modified by a speaker or writer to facilitate second learners' comprehension.

Phonological simplification processes deal with simplifying the production of complex words. Samples that would be pointed out in this research work are: assimilation, metathesis, vowel insertion and elongation, etc

- Circumlocution is the effective use of coping strategies to sustain or enhance communication. However, this aspect of interlanguage phonology would not be looked into and analysed in this research as it is not applicable to this research work.

- Overgeneralization has to do with the process of extending the application of a rule to items that are excluded from it in the language.

The possible markers of interlanguage phenomenon are interference/transfer, simplification, circumlocution and overgeneralisation. Each of these phenomena are discussed in the subsection below.

\section{Interference/ Transfer}

An important interlanguage phenomenon is interference. Interference refers to the influence of one language (or variety) on another in the speech of the bilingual who uses both languages. According to Weinrech (1953), interference refers to those instances of deviation from the norms of either language which occur in speech bilinguals as a result of their familiarity with more than one language, i.e., as a result of language contact. Interference is often used for instances of negative transfer as interference carries negative connotation and many try to avoid it. Phonological interference is a type of interference which deals with the transfer of sounds or accent of one language into another language.

\section{Simplification}

Simplification or reduction of the language by dropping certain elements is only one consequence of transfer from the native or target language. It is a result of opting for the minimum amount of learning or communication with the limited number of forms or rules available (Richard, 1975).

Selinker (1972) mentioned the cases of errors and presents the statement; "I am hearing him" as being due to simplification. However, this may be an example of transferring irrelevant elements as a result of the learners' attempt to simplify the learning task and not the target language system. Linguistic simplification can then be clearly distinguished from simplification of learning tasks, and the various linguistic achievement strategies employed by the learners can be seen as bridging steps leading from task simplification to linguistic simplification; this is one of the outcomes of task simplification (Mahmoud, 2005). Selinker et al. (1972) maintained that simplification is similar to language transfer and over-generalization. They go further to state that it may be much better to consider simplification as "super-ordinate strategy" with overgeneralization and transfers as types of simplification. 


\section{Circumlocution}

Circumlocution is one component of strategic competence which, along with grammatical competence, sociolinguistic competence, and discourse competence consists of communicative competence (Canale \& Swain, 1980). Savignon (1983) also defined circumlocution as "the effective use of coping strategies to sustain or enhance communication" (Savignon, p. 310). Circumlocution is included in the ACTFL speaking proficiency guidelines as a measure of pragmatic competence (Buck, Byrnes \& Thompson, 1989). However, it is rarely taught and even more rarely mastered in the foreign language classroom (Berry-Bravo, 1993).

To Rababah (2002), training of circumlocution and other communication strategies is pertinent because communication strategies can lead to learning by eliciting unknown or forgotten language items from the conversation. Communication strategies are part of actual language use and the use of a communication strategy should not be considered as an indication of communication failure. For the country, it can be very successful in compensating for the lack of linguistic knowledge and preventing a communication breakdown.

In the opinion of Tarone (1996), native speakers employ communication strategies all the time. When native speakers encounter a situation in which such a person lacks lexical items, they try different means to get their meaning across. However, "avoidance" is a common strategy used by many foreign language learners when they face unfamiliar communication challenges. They may avoid communicating at all in such situations. This avoidance strategy will neither get their meaning across nor help them develop the resources needed to deal with future communication problems. Therefore, the main goal for training students on circumlocution is to develop their confidence, build up their comfort level, and improve their linguistic ability to handle communication problems, so that they will be able to try different means to communicate the intended meaning.

\section{Overgeneralisation of the L2 Patterns}

Overgeneralisation allows learners to make a learning task more manageable to themselves by extending a language rule to linguistic norms where it is not appropriate, or where it would lead to ungrammaticalities due to false analogy with other forms. Based on some research on language acquisition made by Ellis (1994), Gass and Selinker (2008), and Lightbown and Spada (2006), studies have shown that children who learn their first language tend to overgeneralise grammatical morphemes, and overgeneralization of L2 rues affects the second language production of young learners (Ellis, 1994; Gass \& Selinker, 2008; Lightbown \& Spada, 2006).

The identified phenomenon of interlanguage transfer, circumlocution, overgeneralization and simplification will serve as the theoretical tenets for the evaluation of the data under investigation in this study.

\section{Methodology}

To address the key objectives of this research, the qualitative and quantitative methods are adopted. The studied participants are reliable and confident. Newscasters are selected because it is believed that they acquire the minimum education and they are trained on the job. The researcher composed an official letter which was addressed to the news organisations. Attached to the official letter was a structured questionnaire used to conduct interviews at the radio 
stations visited. This study employs an experimental research design as it allows for a comparative analysis of the phonology of the respondents, since they all do not come from the same region in Ghana and are not of the same social status or educational background. Hence, this design enabled the researcher to gather data from a wide range of respondents on the phonology of Ghanaian newscasters.

The studied population consists of radio station newscasters in Cape Coast, Ghana. A total number of twelve (12) samples were gotten from the four (4) radio stations that were visited and three respondents were interviewed in each radio station. Ogula (2005) posits that sampling is a process or technique of choosing a subgroup from a population to participate in a study. It is the process of selecting a number of individuals for a study in such a way that the individuals selected represent the large group from which they are selected. In this study, the sampling procedure used for selecting the subject is random sampling. In spite of the random selection, the researcher made sure that these respondents reflected the various linguistic backgrounds of Ghanaians. These respondents were all graduates of the university as well. Ten men were interviewed; out of those men, eight of them were middle aged, the last two were around the age of fifty, while two were females. This is because these respondents were interviewed randomly.

Validity is defined as the extent to which an instrument is measured based on what asserts to or is gotten online or elsewhere (Blumberg et al., 2005). There was an inclusive participation which involved the researcher interviewing the respondents with an audio recorder. This shows that the data gotten by the researcher is first-hand. The data collected would be analysed through the use of Praat software to generate objective results.

All of the respondents are Ghanaians with eleven of them from the Central region and the remaining one from the Eastern region. All of the respondents are from the Akan speech community, except one and those from this speech community speak Fante as their native language or acquired as a second language, including the only one from the Ashante region.

The table below shows a summary of the geographical and linguistic profiles of the respondents.

Table 1: Geographical and Linguistic Profiles of the Respondents

\begin{tabular}{|l|l|l|l|}
\hline Nationality & Region & Tribe & Number of Languages Spoken \\
\hline Ghanaian & Central & Akan (Fante) & 4 (English, Fante, Ga \& Twi) \\
\hline Ghanaian & Central & Akan $\{$ Fante $\}$ & 3 (English, Fante, Twi \& Latin) \\
\hline Ghanaian & Central & Akan (Brouhafo) & 2 (English \& Twi) \\
\hline Ghanaian & Central & Akan (Fante) & 2 (English \& Fante) \\
\hline Ghanaian & Central \& Eastern & Undisclosed & $\begin{array}{l}\text { (Ewe, Ga, Ga Dangbe, French, } \\
\text { Akwapim, Fante \& English) }\end{array}$ \\
\hline Ghanaian & Central & Akan & 3 (English, Ashanti \& Fante) \\
\hline Ghanaian & Central & Akan (Fante) & 3 (English, Fante \& Twi) \\
\hline
\end{tabular}


International Journal of Literature, Language and Linguistics

ISSN: 2689-9450

Volume 5, Issue 1, 2022 (pp. 1-16)

www.abjournals.org

\begin{tabular}{|l|l|l|l|}
\hline Ghanaian & Central & Akan (Fante) & 2 (Fante \& English) \\
\hline Ghanaian & Central & Ashanti (Ashanti) & 3 (English, Ga \& Twi) \\
\hline Ghanaian & Central & Akan & 2 (Akan \& English) \\
\hline Ghanaian & Central & Akan (Fante) & 3 (English, Fante \& Twi) \\
\hline Ghanaian & Central & Akan (Fante) & 3 (English, Fante \& Twi) \\
\hline
\end{tabular}

This table shows the nationality of the speaker that all of them are Ghanaians, all of them are from the Central region and the Akan tribe, while most (eleven) are Fantes.

\section{DATA ANALYSIS}

\section{Simplification}

Here, there are elements of simplification, whereby these speakers introduce the CCV of the Akan language to enable them produce these words easily. Consonant reduction, simplification, re-syllabification and restructuring were employed.

\section{Samples of Simplification}

Table 13

\begin{tabular}{|c|c|c|c|c|c|}
\hline Datum & Sample & Word & $\mathrm{BrE}$ & GE & $\begin{array}{l}\text { Simplification } \\
\text { Procedure }\end{array}$ \\
\hline 1 & $\mathrm{D}$ & Language & /2æygwidz/ & [rænguwej] & $\begin{array}{l}\text { Resyllabification } \\
\text { and Restructuring }\end{array}$ \\
\hline 3 & $\mathrm{C}$ & English & /InglIJ/ & [IngI|II] & Resyllabification \\
\hline 4 & $\mathrm{D}$ & Accent & /aksent/ & [æsent] & Cluster Reduction \\
\hline 5 & $\mathrm{C}$ & Acquire & /akwaia/ & [ækwa:d] & $\begin{array}{l}\text { Restructuring and } \\
\text { Resyllabification }\end{array}$ \\
\hline 8 & $\mathrm{C}$ & Little & /IItol/ & [liti:r] & $\begin{array}{l}\text { Cluster } \\
\text { Simplification }\end{array}$ \\
\hline 8 & $\mathrm{D}$ & Infact & /Infækt/ & [Infæt] & Cluster Reduction \\
\hline 9 & $\mathrm{~B}$ & Virtue & /vz:tju:/ & [vz:tryu:] & Resyllabification \\
\hline 10 & $\mathrm{~A}$ & Polytechnic & /polıteknık/ & [pori:tekınık] & $\begin{array}{l}\text { Resyllabification } \\
\text { and Restructuring }\end{array}$ \\
\hline 11 & $\mathrm{C}$ & Official & lafifarl & [ว:frJIa:] & $\begin{array}{l}\text { Resyllabification } \\
\text { and Resturcturing }\end{array}$ \\
\hline 12 & $\mathrm{~A}$ & English & /InglII/ & [IngIlis] & Resyllabification \\
\hline
\end{tabular}

In the table above, it has been observed that there are instances of cluster simplification and reduction, as well as words being re-syllabified and restructured. For instance, in datum one, sample D, it is evident that this word has gone through some kind of resyllabification and 
restructuring. As a vowel - [u:] was added to the second syllable of the word, resyllabifying the word into a three-syllable word, thereby simplifying the word enough for the speaker to produce easily, based on the CVCV of the Akan language.

In Datum three, sample $\mathrm{C}$, another resyllabification and restructuring occurred, as the $/ \mathrm{y} /$ was dropped and represented with [n], then /g/ was placed in another syllable together with the vowel [I], since the Akan language lacks closed syllables and so as to breakdown and simplify the word, thereby changing a two syllable word into a three syllable word.

In datum four, sample $\mathrm{D}$, a kind of cluster reduction took place as the two-syllable word was reduced to a one-syllable word. In a way to simplify the cluster $/ \mathrm{ks} /$, because the Akan language does not have one, $/ \mathrm{k} /$ is deleted for easy production of the word, hence the reduction of the cluster.

In datum five sample C, the word "acquire" has two syllables and a triphthong which does not exist in the Akan sound inventory; therefore, the speaker found a way to simplify the word by restructuring and also resyllabifying it. $[\mathrm{u}]$ is inserted in between $/ \mathrm{k} /$ and $/ \mathrm{w} /$ and then deleting the triphthong and replacing it with the long vowel /a:/, thus, changing the word from a twoword syllable into a three-word syllable.

In datum eight sample $\mathrm{C}$, a vowel was added to the word to achieve the CVCV of the Akan language, as [I] was inserted in between / $t /$ and the supposed / $/$ / sound which was changed to [r] as a result of the lack of that sound in the Akan sound inventory. It can be said that the cluster was simplified.

In datum eight sample $\mathrm{D}$, the sound $/ \mathrm{k} /$ was deleted by the speaker, thereby causing a consonant cluster reduction. Since it is difficult for this speaker (like some other second language learners of English whose first language lacks consonant clusters) to produce the sounds $/ \mathrm{kt} / \mathrm{together}$ they deleted the/k/ sound, thereby producing the $/ \mathrm{t} /$ alone for the sole purpose of simplification.

In datum nine sample B, the word "virtue" was resyllabified into a three-syllable word instead of two, as the sound [I] was placed in between $/ \mathrm{t} /$ and $/ \mathrm{y} /$, giving the word another syllable in the medial position for an easy production of the word-simplification.

In datum ten sample A, since the Akan language lacks a closed syllable, the word "polytechnic" was restructured by this speaker in a way that would be easier for him to produce the word, thereby, applying the CVCV rules of the Akan language by moving the [l] sound to the second syllable and then placing the vowel sound [I] beside the $/ \mathrm{k} /$ sound and achieving CVCV rule of the Akan language.

In datum eleven sample $\mathrm{C}$, after the deletion of the schwa sound in the third syllable of the word "official" (which is not present in the Akan sound inventory), vowel sound [I] was placed beside the $/ \mathrm{J} /$ sound for the purpose of simplification. In addition, the three-syllable word was resyllabified and restructured into a four-syllable word.

Like datum three sample $\mathrm{C}$, datum twelve sample $\mathrm{A}$, was resyllabified by this speaker by introducing the vowel sound [I] placed beside the $/ \mathrm{g} /$, thereby resyllabifying a two-syllable word into a three-syllable word. 
International Journal of Literature, Language and Linguistics

ISSN: 2689-9450

Volume 5, Issue 1, 2022 (pp. 1-16)

www.abjournals.org

In the course of this study, some simplification processes came to light, such as syllabic elision, substitution, assimilation, metathesis, nasalization, etc. and they would be analysed in the section below.

\section{Phonemic and Syllabic Elision and Substitution}

Here, some phonemes and syllables were deleted, substituted or reduced with or without replacement. This is represented in the table below:

\section{Samples of Phonemic and Syllabic Elision, Substitution and Reduction}

\section{Table 14}

\begin{tabular}{|c|c|c|c|c|}
\hline Datum & Sample & Words & $\mathrm{BrE}$ & $\mathrm{GE}$ \\
\hline One & $\mathrm{A}$ & English & /InglIJ/ & [Ingri]] \\
\hline One & $\mathrm{B}$ & Official & lav $f_{I} \int a \mid$ & [ว:f $\left.f_{\mathrm{I}} \int \mathrm{ia}:\right]$ \\
\hline One & $\mathrm{C}$ & Develop & /divelarp/ & [diverop] \\
\hline Two & $\mathrm{A}$ & Accent & /aksent/ & [æsent] \\
\hline Three & A & Dumb & $/ \mathrm{d} \Lambda \mathrm{m} /$ & [dæmb] \\
\hline Three & B & Pronunciation & 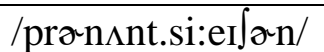 & [prounaunsi:er]In] \\
\hline Four & A & Region & /ri:dzarn/ & [ri:jin] \\
\hline Four & B & Think & /eInk/ & tink] \\
\hline Four & $\mathrm{C}$ & Mother tongue & $/ \mathrm{m} \Lambda \partial \partial \mathrm{rt} \Lambda \mathrm{y} /$ & [mæda:өæng] \\
\hline Five & A & Eastern & /i:starn/ & [i:stin] \\
\hline Five & $\mathrm{C}$ & Acquire & /akwair/ & [ækwa:] \\
\hline Six & B & Probably & /probabali:/ & [probli:] \\
\hline Seven & $\mathrm{A}$ & Central & $/$ sentral/ & [sentra:] \\
\hline Seven & B & Formal & /fo:mal/ & [fo:ma:] \\
\hline Seven & $\mathrm{C}$ & Future & /fju:təar/ & [fyu:tfa:] \\
\hline Eight & $\mathrm{A}$ & Compulsory & /kərmp $\Lambda$ lsari:/ & [konpo:zri:] \\
\hline Eight & B & Both & /boue/ & [bouf] \\
\hline Nine & A & Birth & /bz:ө/ & [bef] \\
\hline Nine & $\mathrm{C}$ & Public & $/ \mathrm{p} \Lambda \mathrm{b} \mid \mathrm{Ik} /$ & [pæbilık] \\
\hline Ten & $\mathrm{A}$ & Polytechnic & /politeknik/ & [pori:tekını] \\
\hline Ten & B & School & /sku:l/ & [sku:] \\
\hline Ten & $\mathrm{C}$ & Children & /tyildran/ & [yidren] \\
\hline Eleven & B & Question & /kwestan/ & /[kwestın] \\
\hline Twelve & $\mathrm{C}$ & People & /pi:pal/ & [pi:pu:] \\
\hline
\end{tabular}

In the table above, it is observed that there are instances of substitution where some sounds are partially or completely replaced with another sound. For instance, in datum two sample A, the syllable in /aksent/ is reduced to a one syllable word /æksent/; this is also applies to datum five sample C, where /akwaio/ - a two syllable word is reduced to a one syllable word as well. These are instances of syllabic reduction.

In datum four sample B /prən^nt.si:eI/ən/, some phonemes were substituted and replaced, such as the schwa sound $/ \propto /$ replaced with $/ \mathrm{o} /$, the vowel sound $/ \Lambda /$ replaced with $/ \Re \mho /$ and the schwa sound in the last syllable also replaced with/I/. Same goes for datum five sample A, datum 
seven sample $\mathrm{C}$, datum eight sample $\mathrm{B}$, datum nine sample $\mathrm{A}$ and $\mathrm{C}$, and datum eleven sample B. The word $/ \mathrm{i}: \mathrm{st} \approx \mathrm{n} / \mathrm{as}$ the $/ \boldsymbol{\gamma} /$ sound is substituted with $/ \mathrm{I} /$, the sound $/ \mathrm{j} /$ and $/ \boldsymbol{\gamma} /$ in word

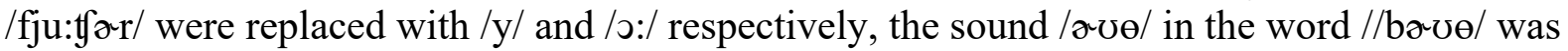
replaced with [ouf] and that of the sound $/ \Theta /$ was replaced with [f] in the word $/ \mathrm{bz}: \Theta /$ and in the word $/ \mathrm{kwes} f \mathrm{f} \mathrm{n} /$; the sound $/ \mathrm{g} / \mathrm{was}$ replaced with [t]. These are instances of substitution.

The presence of elision is evident in datum six sample B, datum seven sample A and B, datum eight sample A, datum ten sample B and datum twelve sample C. In these words, the sound / $/$ was elided either in the medial syllable or the final syllable.

\section{Assimilation}

In this data, there are elements and evidence of progressive and retrogressive assimilation.

\section{Progressive and Retrogressive Assimilation}

\section{Table 15}

\begin{tabular}{|c|c|c|c|c|}
\hline Datum & Sample & Word & $\mathrm{BrE}$ & GE \\
\hline Three & $\mathrm{B}$ & Pronunciation & /pranınt.si:eIJann/ & [prounauosi:eIfin] \\
\hline Four & $\mathrm{A}$ & Region & /ri:dzan/ & [ri:jin] \\
\hline Four & $\mathrm{C}$ & Mother tongue & $/ \mathrm{m} \Lambda \partial \partial r \mathrm{rt} \Lambda \mathrm{y} /$ & [mæda:өæng] \\
\hline Five & $\mathrm{D}$ & Communicate & /kərmjonikeit/ & [ko:minikeIt] \\
\hline Eight & A & Compulsory & /kərmp $\Lambda$ [səri:/ & [konpo:zri:] \\
\hline
\end{tabular}

In the diagram above, there are instances of progressive and retrogressive assimilation. For instance, in datum three sample $\mathrm{B}$, progressive assimilation is evident as the sound [o]

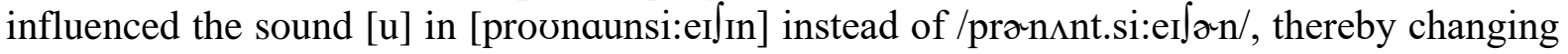
the sounds. Another element of progressive assimilation is evident in datum four sample $\mathrm{C}$ as the preceding sound $/ \partial /$ in $/ \mathrm{m} \Lambda \partial \gamma^{\prime} /$ is given to the succeeding sound $/ \mathrm{t} /$ in $/ \mathrm{t} \Lambda \mathrm{y} /$, thereby changing it to [mæda: ææng]. The element of regressive assimilation is evident in datum five sample D and datum eight sample A, where the following sound [I] in [ko:minikert] instead of /komjonikert/ influenced and attracted the preceding sound [n]. This is also the same case with the latter.

\section{Nasalisation}

Nasalisation is an important part of this data, as some sounds such as $/ \mathrm{y} /$ and $/ \mathrm{m} /$ were being nasalised by the respondents. The instances are illustrated below:

\section{Table 16}

\begin{tabular}{|c|c|c|c|c|}
\hline Datum & Sample & Word & $\mathrm{BrE}$ & GE \\
\hline One & $\mathrm{A}$ & English & /InglII/ & [Ingri]] \\
\hline One & $\mathrm{D}$ & Language & /æærgwidz/ & [rænguwej] \\
\hline Four & B & Think & /eInk/ & [tink] \\
\hline Six & A & Mother tongue & $/ \mathrm{m} \Lambda \partial \partial \boldsymbol{r}^{\prime} \Lambda \mathrm{y} /$ & [mæda:өæng] \\
\hline Eight & A & Compulsory & /kərmp $\Lambda$ [səri:/ & [konpo:zri:] \\
\hline
\end{tabular}




\section{Vowel Insertion and Elongation}

There are also instances of vowel insertion and elongation evident in this data, as some vowels are added to some of the words, while some other words are lengthened by the introduction of long vowel sounds in place of short vowel sounds. Instances are shown below:

Table 17

\begin{tabular}{|c|c|c|c|c|}
\hline Datum & Sample & Word & $\mathrm{BrE}$ & $\mathrm{GE}$ \\
\hline One & $\mathrm{D}$ & Language & /længwidz/ & [rænguwej] \\
\hline Eight & A & Compulsory & /komp $\Lambda$ lsori:/ & [konpo:zri:] \\
\hline Nine & $\mathrm{C}$ & Public & $/ \mathrm{p} \wedge \mathrm{b}[\mathrm{Ik} /$ & [pæbilik] \\
\hline Ten & $\mathrm{A}$ & Polytechnic & /politeknik/ & [pori:tekınık] \\
\hline
\end{tabular}

In the illustration above, it is evident that there are elements of vowel insertions and election, i.e., we have sounds which vowels are added to, thereby lengthening the production of those words. For instance, it is evident that in datum one sample D, /læygwidz/ is lengthened by a sound [u] in [rænguwej]. In datum eight sample A, it is seen that $/ \mathrm{k} ə \mathrm{mp} \Lambda$ [səri:/ has been elongated by changing the $/ \Lambda /$ sound and replacing it with the long vowel sound [0:]. An instance of insertion is evident in datum nine sample $\mathrm{C}$ and datum ten sample $\mathrm{A}$ as /p $\wedge \mathrm{b} \mathrm{l \textrm {lk }} / \mathrm{and}$ /politeknik/ have had vowels inserted into them, such as the vowel sound added to both words in the penultimate syllable of both words.

\section{Metathesis}

An instance of metathesis is also an important aspect of this data. This is illustrated below:

Table 18

\begin{tabular}{|l|c|l|l|l|}
\hline Datum & Sample & Word & BrE & GE \\
\hline Twelve & B & Vernacular & /vərnækjə/ər/ & [væla:kuna:] \\
\hline
\end{tabular}

In the diagram above, there is an instance of metathesis - in datum twelve sample B, the sounds $/ \mathrm{n} \mathfrak{} / \mathrm{in}$ the second syllable is switched and placed in the last syllable, while the sound $/ \mathrm{la} / \mathrm{was}$ placed in the second syllable as well.

\section{Overgeneralisation of the $\mathrm{L} 2$}

Here, there are elements of overgeneralisation whereby the selected respondents overwrite the rules applicable to a certain word and apply them to other words. 
International Journal of Literature, Language and Linguistics

ISSN: 2689-9450

Volume 5, Issue 1, 2022 (pp. 1-16)

www.abjournals.org

\section{Evidences of Overgeneralisation}

Table 19

\begin{tabular}{|l|l|l|l|l|}
\hline Datum & Sample & Word & BrE & GE \\
\hline Three & B & Pronunciation & $/$ prən $\Lambda$ nt.si:eIIən/ $/$ & [prounaunsi:eI]In] \\
\hline Three & A & Dumb & $/ \mathrm{d} \Lambda \mathrm{m} /$ & [dæmb] \\
\hline
\end{tabular}

In the illustration above, it is evident that there are instances of overgeneralisation. For instance, in datum two sample F, the sound $/ \mathrm{n} \Lambda \mathrm{n} /$ in /pron $\wedge$ nt.si:eI $\int 2 \mathrm{n} /$ is replaced with [næon] simply because the rule that applies to the verb of this word which is "pronounce" /pronaonts/ is being overgeneralised, thereby affecting and changing the sound.

In datum three sample $\mathrm{A}$, the bilabial plosive $/ \mathrm{b} /$ is added to the word, which ought to be silent. This is because words with the sound /b/ in them are often produced, hence overgeneralising this rule and applying it to the word "dumb". It could also be argued that these speakers produced these sound based on the orthography/spelling of the word and not the sounds.

Considering the interlanguage differences in the individual respondents' renditions, the findings are presented in spectrograms as follows to identify the areas of differences in the pitch, intensity, formant and pulse. Five recurrent words will be analysed in this manner in a comparative form.
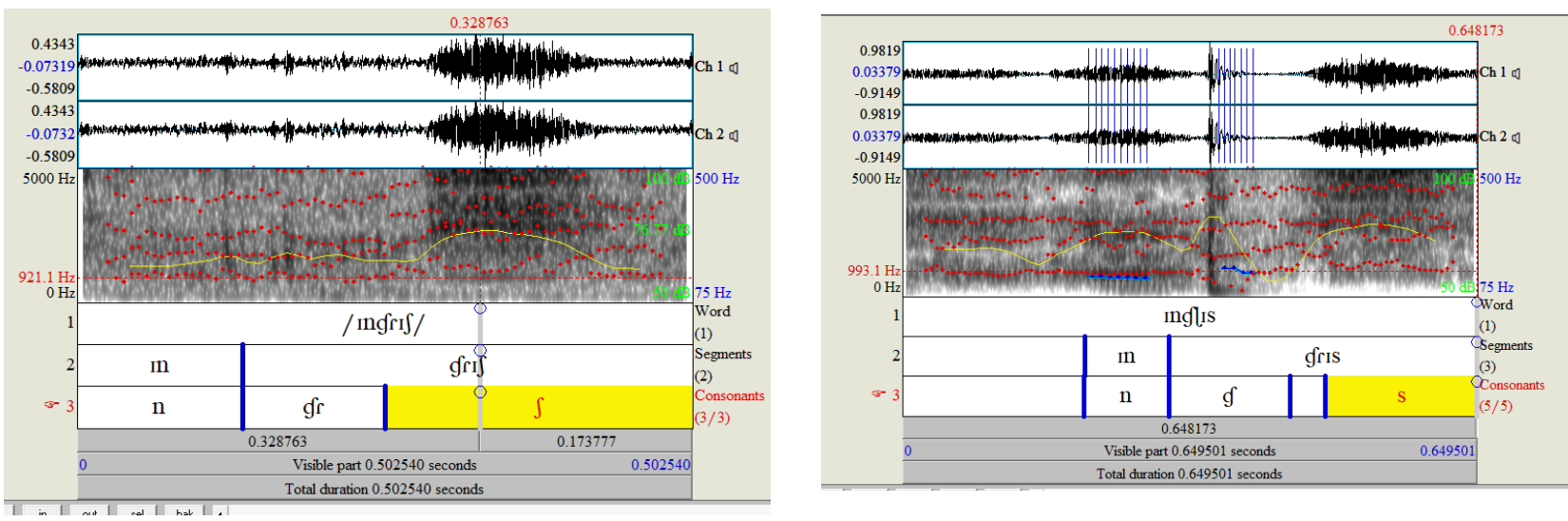

Fig 1 and 2: A Juxtaposition of the realisations of English in datum 1 and datum 12.

Figure 1 above represents the realisation of the word English in datum 1, 1. The spectrogram reveals that the word "English", /InglıJ/, is realised within 0.502540 seconds by the respondent in datum one while the second speaker realises the same word in a duration of 0.649501 seconds. Based on the recording of this data by the researcher, the word is produced slightly differently by both respondents. Taking the post alveolar fricative sound $/ \mathrm{J} /$ into consideration, it is seen that the first respondent produces the sound following the rules of the RP, while the other respondent substitutes the sound with the alveolar fricative [s]. 
International Journal of Literature, Language and Linguistics

ISSN: 2689-9450

Volume 5, Issue 1, 2022 (pp. 1-16)

www.abjournals.org

In addition, the duration of each consonant sound differs as both respondents produce the word using different pitches, intensities, formants and frequencies.

Figure one shows that the respondent produces the alveolar nasal sound /n/ within the duration of 0.135025 , while figure two realises the same phenomenon within the duration of 0.095984 . It is also revealed that in figure one and two, the velar nasal sound $/ \mathrm{g} /$ are both realised within two different durations, with the former within 0.116245 while the latter is realised within 0.136673 .
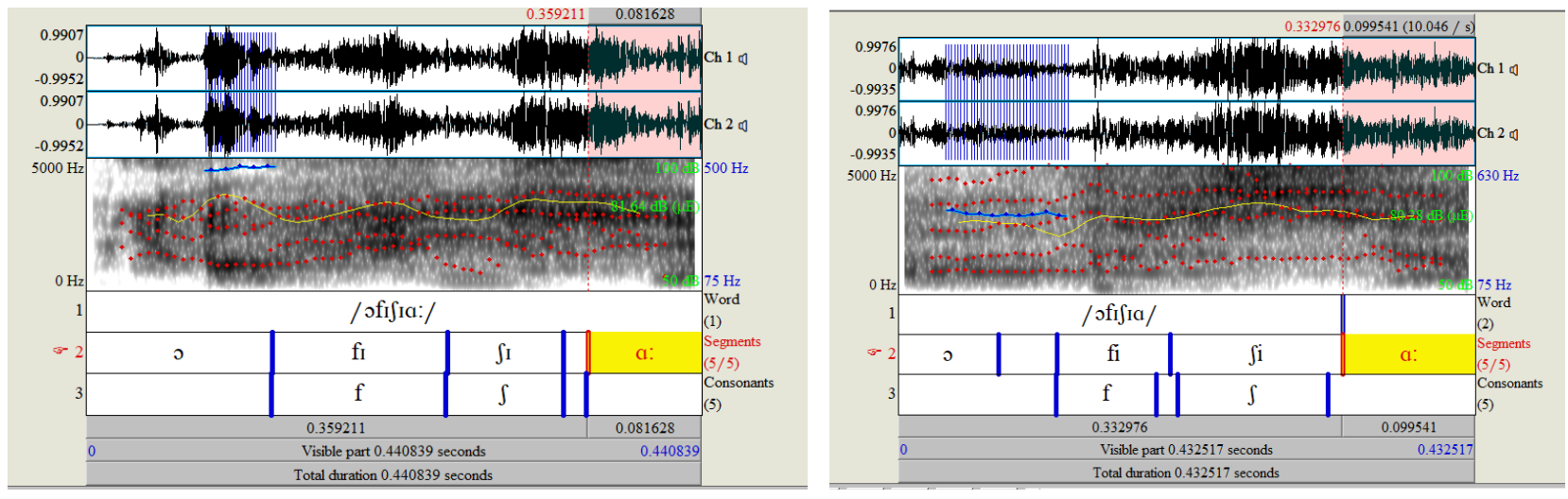

Fig 3 and 4: A juxtaposition of the realisations of official in datum 12 and datum 2 respectively

Here, it is evident that both figures ( 3 and 4 ) have similar features. The realisation of the word "official" is the same; however, the durations of the phonemes differ. The vowel sound [0] is realized in the first figure within $0.133318(75.01 / \mathrm{s})$ duration. On the other hand, it is realised within 0.075220 by the second respondent. The vowel sound [a:] in the former is realised within the duration of 0.81628 , while the latter is within the duration of 0.099541 .
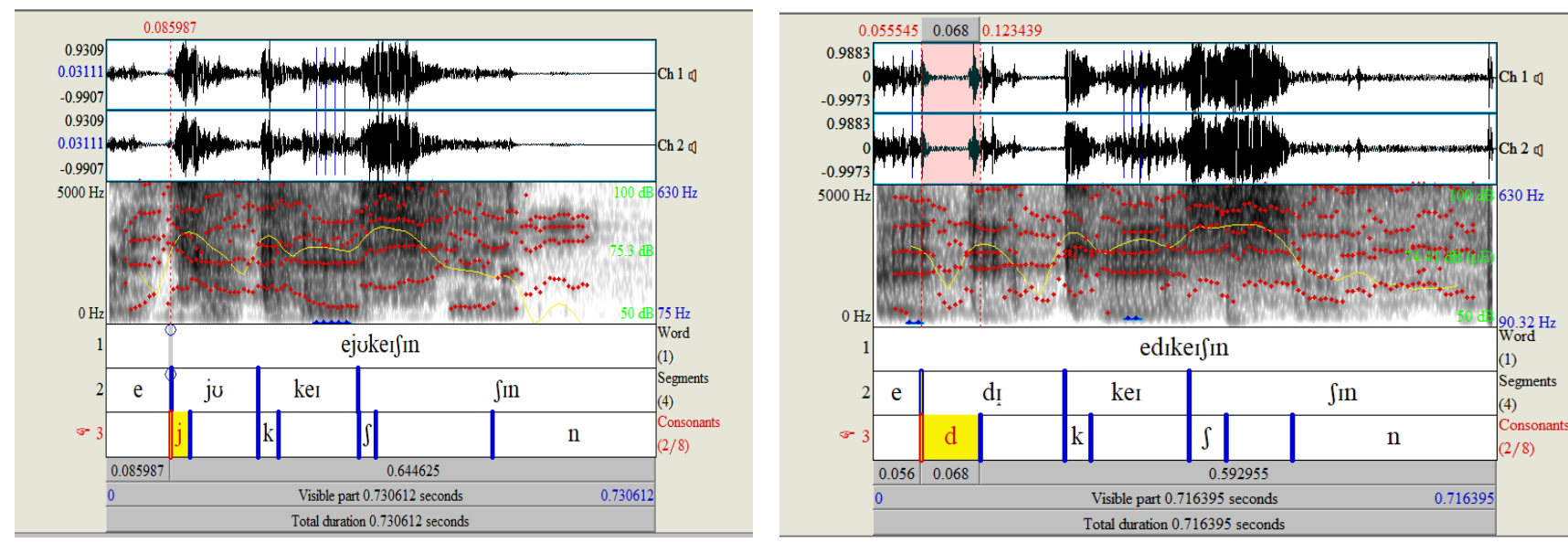

Fig 5 and 6: A juxtaposition of the realisations of education in datum 1 and datum 2 respectively 
It is revealed here that there is a difference between both realisations by both respondents when producing the word "education". The former figure (5) shows that the respondent attempts to produce the consonant sound / $\mathrm{dz} /$ correctly, thereby producing the sound as $[\mathrm{j}]$ within the duration of 0.202173 , while the other produces the sound as /d/ within the duration of 0.068 .

\section{DISCUSSION}

This study examined the speech patterns of selected utterances of Ghanaian newscasters of four different radio stations in Cape coast, Ghana from three different perspectives. The first one focused on not only the juxtaposition of the $\mathrm{BrE}$ and the GE variety, but also the general transfer of the L1 phonemes into the L2 by the respondents in their speech, which is one of the tenets of the interlanguage phonology theory by Larry Selinker. It also went further to observe the aspect of the simplification processes inherent in their speech patterns which have to do with assimilation, nasalisation, metathesis, etc. Lastly, it examined the overgeneralisation of the L2 in their speech as well.

The variation of the rendition of the respondents of this data occurs at the pronunciation level, phonemic changes and some phonological simplification processes. These variations were revealed through the juxtaposition of the British English (BrE) and the Ghanaian English (GhE) as well as the transfer of the L1 features into the L2 speech patterns. This had to do with the substitution of phonemes presents in the L2 with sounds present in the L1 because of the lack of those sounds in the L1. A very obvious feature is the substitution of the weak vowel sound, for instance, schwa sound / / / sound substituted with strong vowels present in the L2. Another feature is the substitution of the $/ / /$ sound with the $/ \mathrm{r} /$ sound, since it does not exist in the sound inventory of the Ghanaian English. This occurred mostly at the word-medial and final position. Moreover, because diphthongs and triphthongs do not exist in the indigenous sound inventory - thereby making it difficult for them to produce the sounds - they were substituted with the single phonemes present in the L1 sound inventory.

Based on the analysis conducted using simplification, it has been deduced that the respondents often simplify their words or sounds when the production of the phoneme or word seems difficult or when it does not exist in their indigenous sound inventory and as a result, they tend to resort to syllable reduction, restructuring and/or resyllabification of the word. In this analysis, instances of some simplification processes - such as progressive and retrogressive assimilation, vowel insertion and elongation, metathesis, nasalization-were also evident in the speech of these Ghanaian speakers of the English language. It has been deduced in this analysis that these Ghanaian speakers tend to overgeneralize some of rules of the English language.

However, it varies at the suprasegmental level in that, during the data analysis of this research work, it was observed that during the comparative analysis, the respondents realised a particular word in a somewhat different manner which included the difference in duration, pitch, formant, intensity and frequency as well.

It has also been observed in the data analysis that the respondents' renditions vary at the pronunciation level which is revealed based on the duration of sounds produced by them. For instance, in the production of the word "English", the two respondents' renditions that were 
International Journal of Literature, Language and Linguistics

ISSN: 2689-9450

Volume 5, Issue 1, 2022 (pp. 1-16)

www.abjournals.org

juxtaposed, the first speaker produced the word within the total duration of 0.502540 , while the other was realised within the total of 0.649501 duration.

\section{CONCLUSION}

This study has been able to examine the speech patterns of selected Ghanaian newscasters through the lens of the tenets of the interlanguage phonology theory by Larry Selinker. This study revealed how the interlanguage phonology could help identify the influences of the mother tongue on the speech patterns of these Ghanaians, as well as the deviation from the rules of the English language, thereby showing that the Ghanaian English does not comply totally with the rules of the English language. However, it is pointed out that regardless of these mother tongue interferences, the Ghanaian English is also a variety of the English language.

\section{REFERENCES}

Adjaye, S.A. (2005), Ghanaian English Pronunciation. New York: The Edwin Mellen Press Akan at Ethnologue, (2019). Twi edition of Wikipedia, the free encyclopaedia.

Ammon, U. (1992), Dominance of English as a Language of Science: Effects on other Languages and Language Communities. Berlin \& New York: Mouton de Gruyter

Bauman, J. W (2009). Introduction to Phonetics and Phonology, Pearson Publisher.

Berry-Bravo, J. 1993. "Teaching the Art of Circumlocution.” Hispania 76: 371-377.

Boadi, L.A (1971). Education and role of English in Ghana. In: J. Spencer (Ed.) The English language in West Africa, pp. 49-65 ( English Language Series). London: Longman grammar

Bobda, S.A. (2000b) "The Uniqueness of Ghanaian English Pronunciation in West Africa". In Studies in the Linguistic Sciences. Vol. 30:2, 185-198.

Buck, K, H. B, \& Thompson, I. (1989). The ACTFL oral proficiency interview tester training manual. Yonkers, NY: ACTFL

Canale, M. (1983). "From Communicative Competence to Communicative Language Pedagogy.” In Richards and Schmidt (Eds.), English for Cross-Cultural Communication. New York: Longman.

Canale, M., \& Sawin, M. 1980. "Theoretical Bases of Communicative Approaches to Second Language Teaching and Testing." Applied Linguistics 1: 1-47.

Charles, M,. \& Solace, Y. (2008): "The Structure of the CCV Syllable of Akan" Kwame Nkrumah University of Science.

Clark, J. \& C. Yallop (1990-1994). An Introduction to Phonetics and Phonology. Cambridge: Blackwell Publishers

Clark, J., Yallop, C. and Fletcher, J. (2009). An introduction to Phonetics and Phonology, 3rd edn; Oxford: Blackwell Publishers

Collins, B. \& Mees, I. (2009). Practical Phonetics and Phonology, Vol13; London

Dako, K. (2001). "Some Thoughts about the use of Dental Fricatives by Students at the University of Ghana". Exploration: Journal of the University of Ghana. Vol.2. Ghana University Press.

Dako, K. (2001). The Sound System of Ghanaian English. In A.B.K. Dadzie (ed.) Exploration: Journal of the English Department. 
Davenpart, M. (2010). Introducing Phonetics and Phonology, 3rd edn; Library of Congress Cataloguing.

Fang, I. (1997). History of Mass Communication; Six Information Revolutions, P. 280, Bouston, USA: Focal Press.

Gussenhoven, C and Jacobs, H (2011). Understanding Phonology, Great Britain: Hodder Education.

Gyasi, I. K (1990) "The State of English in Ghana". English Today 23, 24-26

Huber, M. (2008). Ghanaian English: Phonology. In R. Mesthrine (Ed.) Varieties of English: Africa, South and Southeast Asia. Berlin: Mouton de Gruyter.

Jombadi, A. (2015). Basic Studies in English, Department of Linguistics African and European Languages: Kwara State University, Malete.

Kachru, B.B, (1983), "Models for Non-Native Englishes". In Kachru, 1983:31-54

Koranteng, L. (2006). Ghanaian English: A description of the South System and Phonological Features. PhD Dissertation, University of Ghana, Legon

Mching, L., Gordon, M.J. and Gordon, M. (2003). Sociolinguistics; Method and Interpretation. Oxford: Blackwell

Mesthrine (ed.) Varieties of English for Africa, South and South East Asia. Mouton de Gruyter, Berlin: New York.

Milroy, L. (2002). The Handbook of Language Variation and Change. Cambridge: Cambridge University Press

Nathan,G. (2008). Phonology: A Cognitive Grammar Introduction. USA

Ngula, R.S, (2011). Ghanaian English: Spelling Pronunciation in Focus. Language in India $11(2)$.

Ngula, R.S. (2014). Hybridized Laxical Innovations in Ghanaian English. Nordic Journal of African Studies 23 (3), 21-21.

Ofori, S, G. (2012). A study of the Segmental Feature of the Spoken English by Some Basic School Pupils. Unpublished MPhil. Thesis, University of Ghana, Legon.

Ofori, S. G., Duah, I. and Minutah, K.C. (2014). Exploring the Feasibility of Proposed Ghanaian English Pronunciation Standard. (Journal of Education and Practice, Vol.5, No, 22)

Rababah, G. (2002). "Second Language Communication Strategies: Definitions, Taxonomies, Data Elicitation Methodology and Teachability Issues. A Review Article.” ERIC ED472698.

Roach, P.J. (2009). English Phonetics and Phonology, Cambridge: Cambridge University Press.

Savingnon, S. 1983. Communicative Competence: Theory and classroom practice. Reading, MA: Addison.

Yule, G. (2006). The Study of Language, 3rd edn; Cambridge: Cambridge University Press. https://www.media.io/convert/mp3-to-wav.html. 